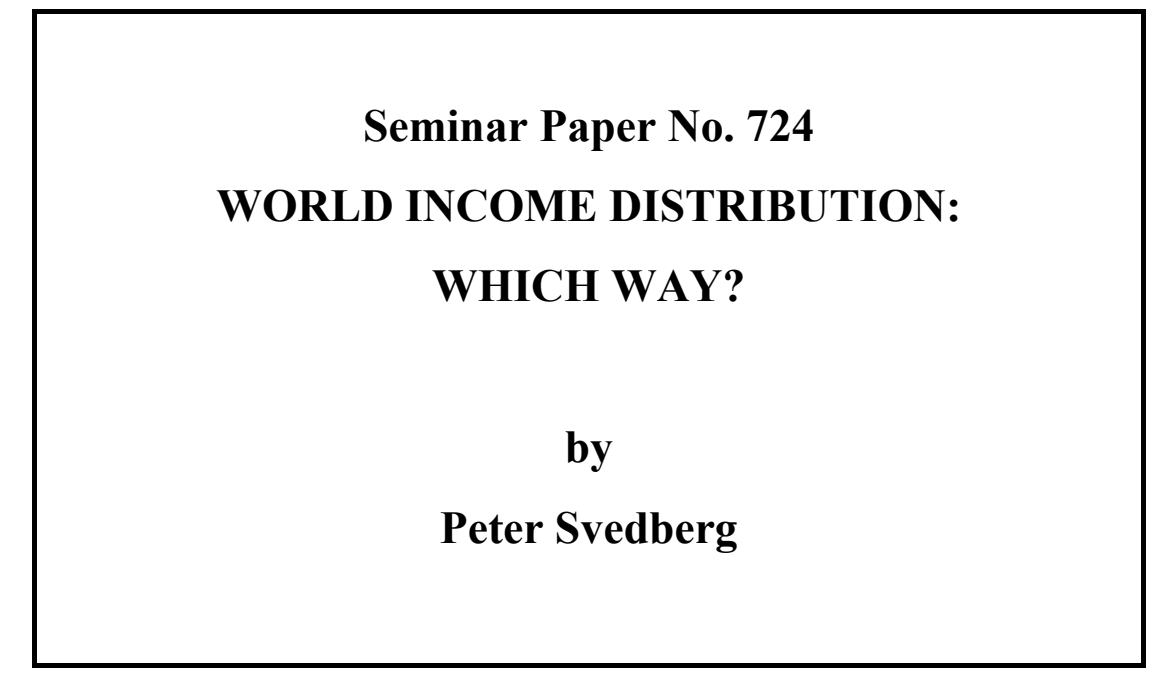

Peter Svedberg

INSTITUTE FOR INTERNATIONAL ECONOMIC STUDIES Stockholm University 
Seminar Paper No. 724

World Income Distribution: Which Way?

by

Peter Svedberg

Papers in the seminar series are published on the internet in Adobe Acrobat (PDF) format.

Download from http://www.iies.su.se/

Seminar Papers are preliminary material circulated to stimulate discussion and critical comment.

September 2003

Institute for International Economic Studies

S-106 91 Stockholm

Sweden 


\section{World Income Distribution: Which Way?}

\section{PETER SVEDBERG}

Over the past few years, a large number of studies have aimed at estimating changes in relative income distribution across countries and globally. Some of the studies find the distribution to have worsened considerably, others that it has become more even. One objective of this article is to identify and quantify the reasons for these conflicting results. Another objective is to highlight the difference between changes in relative and absolute income distribution. While the relative distribution over the entire range of countries seems to have improved somewhat over the past 2-3 decades according to the most relevant indicators, the absolute income gaps between rich and poor countries have widened considerably. It is further demonstrated that these gaps will inevitably continue to grow for many decades to come.

Key words: income distribution, growth, measurements, developing countries, population JEL classification: D31, D63, F0, I3, J11, N3, O15, O47

Lenght of article: 12595 words 
Peter Svedberg is professor of development economics at the Institute for International Economic Studies, Stockholm University, Sweden. He would like to thank Marian Radetzki, Jakob Svensson and, especially, an anonymous referee for helpful comments on earlier drafts. Thanks also to José Mauricio Prado Jr for excellent research assistance and Christina Lönnblad for editorial assistance. Financial support from the Parliamentary Commission on Sweden's Policy for Global Development (Globkom) and the Swedish International Development Cooperation Agency (Sida) is gratefully acknowledged. All standard caveats apply. The paper is an update and thoroughly revised version of IIES SP $698(2001)$.

E-mail: peter.svedberg@iies.su.se 


\section{INTRODUCTION}

Several inter-related issues concerning income distribution in the world have come to the forefront in recent years. A main stimulus has been the many efforts to renew growth theory since the seminal works of Lucas [1988] and Romer [1990], which pose new questions for distribution. Studies of income distribution have also been helped by improvements of the database, despite considerable remaining shortcomings. The new empirical evidence on distribution is not always congruous, however.

One of the contending issues is whether there is a general tendency for income distribution within countries to become more unequal over time in the wake of economic growth and globalisation. Extended and improved data now allow this question to be addressed for some 50 countries. The estimates suggest that in a few countries, income distribution has turned significantly more uneven, and in another small number of countries, significantly more even. In the great majority of the 50 countries, however, income distribution, measured in different ways, has remained more or less unaltered between the individual years compared [Li et al., 1998; Sala-i-Martin, 2002]. Some investigations, based on cross-country observations, find economic growth to have a neutral effect on income distribution in general (e.g. [Dollar and Kraay, 2002]). Ravallion [2001] shows that 'this aggregate picture hides more than it reveals', i.e. that individual country experiences are much too split for an average to make much sense. ${ }^{\mathrm{i}}$

Also the reverse link has received renewed interest. In contrast to earlier conventional wisdom, a string of studies in the mid 1990s found an equal distribution of incomes within countries to be beneficial for economic growth in subsequent periods [Alesina and Rodrik, 1994; Persson and Tabellini, 1994; Clarke, 1995; Perotti, 1996]. 
More recent findings suggest that this result must be qualified [Deininger and Squire, 1998; Forbes, 2000; Barro, 2000]

Another intensively studied question is whether there has been a change in absolute poverty over time. The World Bank [2000/01] and associated researchers [Chen and Ravallion, 2001] find the share of absolute poor in the developing world to have marginally declined (from 28 to 23 per cent) between 1987 and 1998, and the number of poor people to have remained more or less unaltered (at about 1.2 billion). These results are now contested. Reddy and Pogge [2002] and Deaton [2001] question the method used to construct the P\$1 poverty line. Sala-i-Martin [2002] finds a considerably lower incidence of poverty in the world and, most notably, that the $\mathrm{P} \$ 1$-a-day poverty rate has declined dramatically, from 20 per cent in the early 1970s to 5 per cent in 1998 .

In the past few years, an extensive literature has studied a related controversial question: How has the relative distribution of incomes developed over time, across countries and globally? This is the main question to be addressed in the present article. I will attempt to explain why the various studies have reached completely different results. In order to economise on space, only studies published in the last few years are covered.

The most alarming estimates emanate from the United Nations Development Program [UNDP, 1999] and the World Bank [2000/01]. Both find that the ratio of per capita incomes in rich and poor countries (defined differently; see below) has doubled since 1960, while according to other studies, the distribution has remained relatively stable (see Table 1). The two studies reporting the most encouraging picture of world income distribution are Melchior et al. [2000] and Sala-i-Martin [2002]. Applying 
different distribution measures, they conclude that income inequality across countries (and globally) was substantially reduced between 1970 and 1998.

[Table 1 about here]

The conflicting results to a large extent stem from researchers having used different methods for estimating per-capita income (section II) and having applied different measures of income distribution (section III). Differences in how countries are selected and weighted according to population size is also part of the explanation (section IV). Yet another reason is that different time periods have been examined (section V). It is also notable that some studies are confined to estimating inter-country distribution, while others take a global perspective by also incorporating intra-country distribution (section VI). The reliability and relevance of the basic income and population data used in the literature are assessed in section VII.

This article further focuses on a dimension of world income distribution largely neglected throughout the growth-cum-distribution literature, namely the absolute distribution of incomes across countries (section VIII). Almost all measures used in the distribution literature are indicators of relative distribution. It will be shown that the divergence - increased absolute income gaps — between the poor countries in Africa, Asia and the Americas and the rich countries in the OECD area has increased notably since 1970 and that further divergence is inevitable for at least one or two generations to come. A summary of past developments and main conclusions is given in section IX and some reflections concerning the future close the article in section X.

\section{THE INCOME MEASURES}


Several studies use national-account GDP data, converted to US dollars at the current exchange rates (denoted FX\$ in Table 1) as a proxy for (per capita) income All these studies find very large income discrepancies across countries and that the differences have increased markedly with time. This result holds regardless of which measure of income distribution is employed and irrespective of other methodological differences (to be discussed below). In sharp contrast, none of the studies reporting unchanged or improved income distribution has used $\mathrm{FX} \$$ income data from national accounts.

The most common alternative (or additional) income measure used in the studies is also based on per capita GDP from national accounts, but adjusted for differences in purchasing power parity (PPP) across countries. The PPP-adjusted income estimates (P\$) are obtained using the same relative 'international' prices for valuing all goods and services in each and every country. These adjusted income measures hence take into account that the relative prices for goods and services only sold locally in relation to the prices of goods and services facing international competition (traded goods) are significantly lower in poor than rich countries. The per capita P\$ income therefore differs the most from FX\$ income for the poorest countries. For example, in 1999, the estimated per capita income in Ethiopia was P\$600, as compared to FX\$100. (The World Bank [2000/01: Tables 1 and 1a] provides data for more than 200 countries.)

Melchior et al. [2000] and Sala-i-Martin [2002] derive annual estimates of international income distribution since 1970, alternately employing FX\$ and P\$ income data-while holding all other entities in the estimations constant. When the estimates are based on FX\$ data, they find a marked increase in inter-country inequality by all their distribution indicators. When using P\$ incomes, they find the distribution to have 
notably improved by the late 1990s. The unquestionable conclusion is that the choice of income measure is a major determinant of the divergent results in the literature. (Schultz [1998], Firebaugh [1999] and Radetzki and Jonsson [2001] report similar comparative results.)

\section{(a) The FX\$ Income Estimates}

When it comes to making international comparisons of material living standards across countries, there is wide agreement among economists that FX\$ income data are not appropriate, for several reasons. ${ }^{\text {ii }}$ One is that the official exchange rates in many countries have been (and in some, still are) distorted (often overvalued). This is particularly true for the many poor countries where the currency is non-convertible, trade barriers are high, and capital movements controlled by the government.

A related problem is that a discrete changes in the official exchange rate has a proportional effect on per-capita income when valued by FX\$. This is probably the most important reason why the studies employing $\mathrm{FX} \$$ income data have found such a drastic deterioration in the distribution of income across countries. The majority of the poor countries have recurrently devalued their currencies since the 1960s. It is not the case, however, that the purchasing power of the incomes of the population falls in strict proportion to a devaluation. The (intended) main effect of a devaluation is usually to raise the domestic relative price of tradable to non-tradable goods, which will have different effects on the incomes of different population groups, while leaving average real income more or less unaffected. 
Furthermore, FX\$ per capita incomes imply implausibly large differences in material living standards across countries. Ethiopia, Chad, Somalia, Haiti and other very poor countries have a per capita income of around FX $\$ 150$ [World Bank, 2000/01]. In relation to the corresponding income in the US, this suggests a ratio of about 0.005 . It seems impossible that the average person in these poor countries should only consume 0.5 per cent of what the average person in the US does (while about 2 per cent of US consumption when comparing P\$ incomes). Moreover, incomes are unevenly distributed within these poor countries, which implies that the lowest quintile only has some 20-40 FX\$ to live on per annum. Such low incomes suggest a significantly higher mortality rate resulting from undernutrition and illness in the poorest of countries than what is actually observed [Pritchett, 1997].

\section{(b) The P\$ Income Estimates}

That FX\$ income estimates are inappropriate for international comparisons of material living standards does not mean that the $\mathrm{P} \$$ data are flawless, however. One problem is that P\$ estimates from the International Comparison Program (ICP) have only been derived for selected years in what is certainly nowadays a large, although not complete, number of countries (about 115 in 1996, but only 16 in 1970) [ICP, 2002]. The estimates for other countries (and years), including many of the poorest countries, are 'extrapolations' of unknown reliability. As pointed out by Maddison [1995], different P\$

per capita income estimates for a country the size of China (not covered in the ICP) vary by a factor of three. 
The international prices used to derive P\$ income estimates are 'simply the reciprocal of the purchasing power parity of the US' $[I C P, 2002]$. These 'international' prices, by which goods and services in all countries is valued, hence mirror the production structure in the US and the preferences of American consumers. These preferences (and prices) do not unambiguously reflect the relative value of goods and services in all other countries. Any alternative (equally arbitrary) uniform relative price structure would produce a partly different ranking of countries in terms of per-capita income.

A related issue is the fact that the standard P\$ income estimates (from the ICP) do not take into account that people in poor countries, where the relative price of nontradables is low, consume more of these relatively inexpensive items, i.e. they substitute such goods for relatively more expensive traded goods. This means that a so-called substitution bias is built into the P\$ estimates. Dowrick and Akmal [2001] provide income estimates corrected for this bias, which suggest smaller inter-national differences in incomes than indicated by FX income data, but larger than indicated by the P\$ data. There are many additional, unresolved problems with the P\$ estimates from the ICP, such as measuring quality differentials of products and valuing non-marketed services [Deaton, 2001; Rao, 2002].

Nonetheless, there is wide agreement that even though the P\$ income data contain many remaining imperfections, these are more relevant than FX\$ data and there is a recurrent debate on how they could be improved (see the many papers presented at the International Conference on ICP in 2002 [World Bank, 2002b]). It is somewhat surprising, however, that very little space has been devoted to assessing the P\$ data used 
throughout the literature on world income distribution. The main exceptions are Dowrick and Akmal [2001] and Dikhanov and Ward [2002], who derive income data corrected for substitution bias - while still finding the inter-national income distribution to be largely unaltered over time (see also [Dowrick and Quiggin, 1997]).

\section{THE DISTRIBUTION MEASURES}

The income distribution measures can broadly be divided into two categories. The first set of measures is in the form of ratios of per capita incomes in the 'richest' and 'poorest' countries. The other category comprises measures taking the income distribution over the entire range of countries into account. The Gini coefficient is the most commonly employed measure in this category, but also the Theil index, Log-variance, and Squared Coefficient of Variation $\left(\mathrm{CV}^{2}\right)$ are used (Table 1). ${ }^{\mathrm{iii}}$

\section{(a) The Lorentz Curve}

The two sets of measures of income distribution in a population (be it one country or the 'world') can be derived from a Lorentz curve - the unbroken curve $\mathrm{L}_{0}$ in Figure 1. The curve traces out the accumulated population's share of total incomes. In this particular example, the curve indicates that the 10 per cent poorest have about 1.5 per cent of total incomes, the 20 per cent poorest have 3.5 per cent of total incomes, etc. The curve further shows the 10 per cent richest to have half the total incomes ( 50 per cent). The income ratio of, say, the richest 10 per cent in the population to the 10 per cent poorest is hence $50 / 1.5=33.3$.

[Figure 1 about here]. 
The Gini coefficient can also be derived from the Lorentz curve (Figure 1). If all households in a population have the same income, the Lorentz curve will coincide with the diagonal, and the Gini takes the value of 0 . The more uneven is the income distribution, the larger is the Gini coefficient in the interval 0 to 1.0 . The coefficient would take the maximum value of 1.0 if all incomes went to one household in the population. In geometric terms, the Gini coefficient can be calculated as the area $(\mathrm{G})$ between the diagonal and the Lorentz curve (the shaded area) in relation to the area of the triangle $\mathrm{ABC}$ in Figure 1. Quite obviously, the larger the income discrepancies, the larger is area $\mathrm{G}$ in relation to area $\mathrm{ABC}$ - and the higher the value of the Gini coefficient. Gini is consequently a comprehensive measure of the degree of unequal distribution, i.e., it takes the entire distribution into account (as opposed to the ratio measures).

\section{(b) Income Ratios: Ambiguities and Limitations}

In the studies applying income ratios, two alternative principles have been used for delineating 'rich' and 'poor' groups of countries. In some studies, countries have been selected with regard to the size of their population [UNDP, 1999], while this is not the case in others [World Bank, 2000/01]. The difference may seem insignificant, but it is not.

The UNDP calculates the income ratio for the countries with 20 per cent of the world population with the highest per capita incomes, and the countries with 20 per cent of the world population with the lowest per capita incomes. This 'rich' group, with 1.2 billion people, consists of about 60 countries (according to the World Bank's P\$ estimates of per capita income). This group includes the entire Western OECD block as 
well as a large number of middle income countries, such as Mexico and Poland. The weighted (by population size) average per capita income in these 60 countries in 1999 was approximately $\mathrm{P} \$ 20,000$. The group of poor countries, also with 1.2 billion people, includes almost all of Africa south of the Sahara, Indonesia, Pakistan and (the poorer half of) India. The weighted average income in this multitudinous collection of countries in 1999 was about P\$1,600. With this delineation of rich and poor countries, the per capita income ratio becomes $12.5(20,000 / 1,600)$.

The alternative method, used by the World Bank [2000/01], is to set the average per capita income in the 20 richest countries as a ratio to the per capita income in the 20 poorest countries, irrespective of population size. The 20 richest countries only had about 5 per cent of the world's population in 1999 and so had —incidentally — the group of the 20 poorest countries. The 20 richest countries constitute the upper half in the OECD income league together with a few small countries such as Singapore. The (population weighted) average per capita income in these 20 countries is about P\$28,000. Out of the 20 poorest countries, 16 are African and the others are Bangladesh, Nepal, North Korea and Yemen. The average per capita income in these 20 countries is about P\$750. The income ratio of rich and poor countries is 37 in this case, i.e. three times as large as in the previous alternative (12.5). The delineation of 'rich' and 'poor' countries hence plays an essential role for the size of the resulting income ratio. ${ }^{\text {iv }}$

The main advantages of ratio measures - regardless of what income data are used, and whether countries are selected according to population size — are that they are simple to calculate and show the relative difference between the 'extremes' (richest versus poorest). The ratio measures have clear limitations, however. First, the more narrowly the 
groups of rich and poor countries are defined—as just demonstrated— the higher the resultant ratio (cet par), and this delineation is often ambiguous. Second, the ratios do not take income distribution within the groups of rich and poor countries into account. The group of rich countries with jointly 20 per of the world population has per capita incomes ranging from about $P \$ 7,000$ to 38,000 . In the group of countries with the 20 per cent poorest populations, per capita incomes range from $\mathrm{P} \$ 350$ to approximately 2,000. Third, the ratio measures overlook the distribution in (the often large) interval between the 'rich' and 'poor' countries.

\section{(c) Gini Coefficients and Similar Indexes: Ambiguities and Limitations}

Almost all studies using the Gini coefficient (or other comprehensive indexes) and P\$ income data, find either little change in inter-national income distribution since the 1960s or early 1970s, or that the distribution has improved (cf. Table 1). The Gini coefficient has the advantage of considering the entire distribution, but suffers from at least three limitations. The first is that the Gini coefficient is particularly insensitive to income changes in the lowest tail (decile) of the distribution [Pyatt, 1976; Deaton, 2003: 135]. Since what occurs in the lowest tail (among the poorest) is often of particular concern, this limitation is not negligible. Another limitation is that different distributions can produce the same Gini coefficient. A third limitation is that Gini is affected both by changes in per capita incomes and in relative population sizes across countries, without directly revealing the relative contribution of each factor (although decomposition is feasible; see section IV). 


\section{(d) Income Transition}

Both income ratios and Gini coefficients (as well as other comprehensive distribution measures) are silent on income transition. That is, an income ratio or a Gini coefficient estimated at two different points in time can be exactly the same despite numerous countries having changed positions in the income ranking. Considerable transitions have in fact occurred, particularly in the top income group (when measured by FX\$ income; P\$ data for 1960 are incomplete). In 1995, the 10 countries with the highest per capita incomes in the world only included three countries listed in the top income group in 1960, namely the US, France and Switzerland [Radetzki and Jonsson, 2001]. The 10 countries with the lowest per-capita incomes at the same two points in time also differed, though not to the same extent. In this group, several African countries are found on both occasions. It is not possible to capture 'transition' with a measure that can be rendered as a single figure. There is, however, a simple graphic method for revealing transition (see [Jones, 1997]) and there is also the transition-matrices method designed by Quah [1996] and used by Bourguignon and Morrison [2002] and many others.

\section{POPULATION GROWTH}

Population growth has in general been most rapid in the least developed countries and slowest in the richest countries. This variation in population growth has had a significant influence on the development of inter-national income distribution — as estimated by Gini coefficients - over time. As a simple illustration of the importance of population growth for distribution, we shall investigate how the income distribution between two countries - the US and India — changed between 1960 and 1999. Table 2 cites total GDP 
and population in the two countries, as well as their shares of joint income and population in the respective year. Since income and population growth were higher in India than in the US over this period, there was an increase in India's share of both joint income and population. The Gini coefficients and Lorentz curves for the two years are reported in Table 2 and Figure 2, respectively.

[Table 2 about here]

Figure 2 shows that the Lorentz curve shifted positions between the two years as a result of the changed shares of total incomes and population. India's increased share of the joint income contributed to even out the distribution between the two countries, while it was skewed by the country's growing share of the joint population. Incidentally, the two effects cancelled out, leaving Gini unchanged at 0.58 (Table 2). The general interpretation in the growth literature would be that since India's per capita income grew faster than that of the US, India 'caught up' and 'convergence' took place. This example further demonstrates the second limitation of the Gini mentioned above, viz. that two different distributions (Lorentz curves) can produce exactly the same Gini coefficient.

[Figure 2 about here]

Firebaugh [1999] calculated (or rather simulated) the relative influence on Gini of changes in per capita incomes, relative to changes in population size across 120 countries over the 1960-1989 period. He found that had the population shares remained unchanged at the 1960 values (cet par), Gini would have increased by 9.5 percentage points up to 1989 while in fact remaining largely unchanged. During this period, therefore, differences in population growth ensured that inter-country income distribution did not change (despite diverging per-capita incomes). 


\section{THE TIME DIMENSIONS}

\section{(a) Comparison of Individual Years versus Time-series Estimates}

Some studies have estimated changes in inter-national income distribution by comparing distribution measures obtained for two particular years (e.g. [UNDP, 1999; IBRD, 2000/01; Jones, 1997; Radetzki and Jonsson, 2001]). This procedure is labour saving, but can skew the results if the two selected years are not representative. All these studies take 1960 as their initial year. Schultz [1998], who estimated annual Gini coefficients over the 1960-89 period, found that the estimated distribution in 1960 was unusually even and hence, unrepresentative. Moreover, this study, as well as some others (e.g. [Melchior et al., 2000]), reveal a slightly falling trend since the mid 1960s, but also marked annual fluctuations. This begs the question of the statistical significance of the trend; an issue not addressed by the authors, but they are amenably cautious in not overinterpreting their results. The conclusion is nonetheless that studies producing time series distribution estimates are more dependable than those comparing two arbitrarily selected years.

Also the final year varies across the studies based on PPP-adjusted income data. Most investigations end in the late 1980s or early 1990s; only three take us to 1998 or 1999 [Melchior et al., 2000; Sala-i-Martin, 2002; Boltho and Toniolo, 1999]. The first two studies report a smooth decline in inter-country Gini by an accumulated 0.03 points during the 1990s. The latter finds Gini to have declined by 0.02 points between the two years 1990 and 1998. With the Gini distribution measure, there is hence no sign of a pending deterioration in the inter-country relative income distribution. ${ }^{\mathrm{v}}$ 


\section{(b) The Long Time Perspective}

The main reason why many studies take a year in the 1960s as their starting point is that this was the time when the reasonably comparable $(\mathrm{P} \$)$ income data were first produced for most developing countries [ICP, 2002; Maddison, 1995]. Despite the data intractability, a few studies have derived estimates of inter-country income distribution stretching back to 1820 [Bourguignon and Morrisson, 2002], 1870 [Pritchett, 1997], or 1900 [Boltho and Toniolo, 1999]. The historical (PPP-adjusted) income data are mainly taken from Maddison [1995]. The fact that historical income data are only available for a

handful of today's poor countries has been handled differently. ${ }^{\mathrm{vi}}$ Bourguignon and Morrisson lump countries into 33 groups. Within the groups, all countries are assumed to have the same (historical) per capita income and distribution as a 'similar' country in the group for which data could be obtained. Boltho and Toniolo constrain their analysis to the limited number of countries (49) for which Maddison [1995] provides data. Pritchett extrapolates backwards from current incomes to a minimum per capita income level that he finds to be the lowest possible for survival in a population (about $\mathrm{P} \$ 250$ in 1985 prices, or $\mathrm{P} \$ 480$ in 1999 prices) ${ }^{\mathrm{vii}}$.

Despite differences in methodology and the distribution measures employed, the three studies arrive at a unison result: the inter-national income distribution deteriorated sharply up to about the mid 1960s and then levelled off. This result, 'divergence, big time' to borrow Pritchett's expression, can hardly be questioned despite the unreliable and scanty data. No other outcome can be expected, considering the very low per capita income of the great majority of poor countries, including populous India and China, in the 1960s, when the first per-capita income estimates for most of them came forth 
[Maddison, 1995]. These low per capita incomes, in the P\$250-550 (in 1985 PPP prices) range, imply that growth in previous periods must have been very modest, if at all positive. The now richest countries enjoyed a five-fold increase in real per-capita income (some even more) between 1870 and 1950 [Maddison, 1995]. With such spread in growth rates, inter-national income distribution must simply deteriorate.

\section{GLOBAL INCOME DISTRIBUTION}

The issues discussed so far have been inter-country income distribution and changes therein. In a number of studies, the authors further attempt to estimate the 'global' income distribution, i.e. taking both the distribution across and within countries into consideration [Dowrick and Akmal, 2001; Bourguignon and Morrisson, 2002; Dikhanov and Ward, 2002; Sala-i-Martin, 2002]. These studies are based on P\$ income data originating from national accounts. The within-country distributions are estimated with different methods and levels of disaggregation. The first study rely on the quintile data from Deininger and Squire [1996]. Bourguignon and Morrisson, as well as Dikhanov and Ward, use decile income estimates from household expenditure/income surveys. Sala-iMartin estimates a gaussian kernel density function, allowing him to disaggregate intracountry quintile income distribution down to the household level in each country. Gini is the main distribution measure applied (but Theil and LogVar are also used).

With due acknowledgement of the paucity and low quality of the data on internal income distribution in the majority of the developing countries, these studies find (1) the global income distribution to be more uneven than the inter-national distribution (the latter accounts for about 70-85 per cent of the global inequality) and (2) that the global 
distribution has remained relatively stable since the 1960s (a change in Gini by \pm 0.02 points). Going back to 1820, Bourguignon and Morrisson [2002] estimate global income distribution to have deteriorated sharply up to the 1960 s, but to have levelled off since then.

Milanovic [2002] is the first study of global income distribution based on a completely different income data set, viz. household income/expenditure data from 216 country surveys in 1988 and 1993. There is a remarkable similarity with the degree of global inequality he finds and what is reported for the same years by the one study based on national account income data [Sala-i-Martin, 2002]. In both studies, the global distribution in 1988 , as measured by Gini, is estimated at 0.63 . The estimates of global inequality levels hence seem robust to the choice of the income database. However, the two studies find different developments up to 1993. Sala-i-Martin reports a decline in global Gini by 0.02 points, while Milanovic finds an increase of 0.03 points (to 0.66 ). With the Theil index, the divergence in results is even more pronounced.

Space does not allow the reasons for these conflicting results to be examined in detail. Nevertheless, the use of different income data and definitions of countries is central for this controversy. Milanovic divided five populous countries, including China, Bangladesh and India, into two observations by treating the rural and urban populations as two separate 'countries'. He further decomposed the change in the global Gini coefficient geographically and found that 'the main factors underlying the increase in [global] inequality between 1988 and 1993...[were] slower [economic] growth in rural areas in large South Asian countries (India and Bangladesh) and in rural China compared to several OECD countries' [Milanovic, 2002: 85]. That is, the increase in global 
inequality reported in this study was mainly due to increased intra-country inequality (between urban and rural areas) in large Asian countries. ${ }^{\text {viii }}$

No one seems to challenge the notion that intra-country income distribution in both China and India has become increasingly unequal since these countries started to grow notably around 1980 and 1990, respectively [Ravallion, 2001; Deaton, 2001]. It has also been observed, however, that income growth in China and India (and several other developing countries) is considerably lower when estimated from the household surveys (HS) used by Milanovic, than when estimated on the basis of national account (NA) data.

The high income growth rates for China and (less so) India, reported in the national accounts, have had an equalising effect on global income distribution as estimated by Sala-i-Martin [2002]. ${ }^{\text {ix }}$ This equalising effect on global distribution has swamped the unequalising effect of widening income disparities within these two countries. In Milanovic's study, it is the other way around. Here, the small effect on global income distribution of the lower income growth in China and India suggested by the HS data used, has been dominated by the large unequalising effect of the deterioration in internal income distribution in these countries (cf. the above citation). It should be recalled that jointly, the two countries have almost half ( 2.3 billion) of the population in all developing countries ( 5 billion). The different data used to estimate income growth and distribution in these two countries thus have a profound effect on the estimated world income distribution (by Gini and related measures).

It is further notable that the two years covered by Milanovic (1988 and 1993) are too close to allow a firm conclusion regarding long-term trends. The annual Gini estimates of global inequality, derived on the basis of NA data in other studies (e.g. 
[Melchior et al., 2000]), show short-term fluctuations in Gini of $\pm 0.02-0.03$ points. It will hence be interesting to see the update to 1998 of Milanovic's study that is under preparation. Assuming, however, that the estimated increase in Gini by Milanovic is not a temporary, but a sustained, phenomenon, is an increase in Gin by 0.03 points large or small? Milanovic [2002: 72] argues that it is 'very high', making comparisons with estimated changes in individual countries renowned for increased inequality (the US, United Kingdom, China and Chile). However, he himself offers an indirect significance test (in footnote 16), suggesting the estimated difference in Gini coefficient between the two years to be statistically insignificant (as the 95 per cent confidence intervals for 1988 (0.597-0.659) and $1993(0.633-0.687)$ overlap to a considerable extent (by 0.026 Gini points)). ${ }^{\mathrm{x}}$

\section{THE BASE DATA}

It is not possible to say whether Milanovic's income data from HS are more or less reliable and relevant than the NA-based income data used by Sala-i-Martin (and most others). Both data sets are contaminated with measurement errors and omissions, and the population data employed throughout the literature may also be biased.

\section{(a) The Income Data}

The national account data on per capita GDP (whether PPP-adjusted or not), used as a proxy for income in most studies, may contain large systematic distortions (bias). According to the World Bank estimates, per capita income (P\$500-700) in the absolutely poorest countries in 1999 by a tiny margin exceeded what is needed for pure survival in a 
population, estimated by Pritchett [1997] to be around P\$480 in 1999 prices. This may be a statistical delusion. Most likely, the incomes recorded in the national accounts in poor countries are incomplete, one of the reasons being that the indirect incomes generated in the agricultural subsistence sector are systematically underestimated [Heston, 1994]. The production and incomes in other informal (and illegal) sectors are also underreported. There are investigations (of necessity based on defective data) which estimate the unreported incomes in many poor countries to correspond to as much as 50-65 per cent of the national account incomes [Schneider and Enste, 2000].

It is likely, however, that per capita income has been underestimated also in the richest countries. By now, it is widely agreed that inflation has been overestimated over a long period of time, thereby signifying that real income growth has been underestimated. This finding is reported in several studies from the US, based on two completely different estimation methods [Boskin et al., 1997; Hamilton, 2001; Costa, 2001; Hausman, 2003]. The net effect of the underestimation of incomes in both poor and rich countries on world income distribution is impossible to ascertain, but the absolute incomes in the poorest countries are very likely to be underestimated.

The multitudinous household surveys used by Milanovic have been conducted with varying methods, coverage and scrutiny, and are acknowledged by the author to be of uneven quality [Milanovic, 2002: 56-57]. It is also well known that most household surveys suffer from methodological inadequacies and that reported income data are often seriously flawed [Ravallion, 2001; Deaton, 2003]. This is particularly the case in poor developing countries, where expenditures are usually estimated by recalls over such long periods (e.g. 30 days) that many items are long forgotten by the respondents (see Deaton 
[2001] for further discussion). Even in the rich OECD countries, where much more sophisticated estimation technologies are used, household surveys provide shaky income data [Atkinson and Brandolini, 2001]. It is hence not possible to infer that HS data are generally more accurate, and produce more reliable estimates of world income distribution, than NA data. This yet remains an open question.

The choice between NA and HS data must primarily be dictated from what incomes they capture and exclude. The NA data include some incomes that do not accrue to individuals and are hence not used for private consumption (e.g. investments and consumption by governments and non-profit organisations). Conceptually, it would be more satisfying to measure income by the private consumption expenditure part of total incomes. This has not been done in any study, presumably because these estimates, often derived as a residual in the national accounts, are notoriously unreliable. The HS data include a larger share of subsistence incomes, but exclude non-private expenditures (some of which have a direct bearing on individual welfare, such as public schooling and health care). Considering these and many other differences in income coverage (see Ravallion [2001] and Deaton [2001; 2003] for further discussions), it is remarkable that the estimates of the level of global income inequality based on NA and HS data, respectively, match so well (at least for 1988; cf. above).

\section{(b) The Population Data}

Quite recently, the World Bank undertook a drastic revision of its published population data (based on data from national statistical offices and the UN). A comparison between the two World Development Reports [World Bank, 1999/00, 2000/01: tables 3], shows 
that world population growth was revised downward by about 40 per cent for the 1980 s, and 13 per cent for the 1990s. This must be the most radical statistical revision ever completed for an indicator as important as population growth. Strangely enough, no comment whatsoever of the underlying reasons is provided by the World Bank [2000/01], but the revisions can be traced to the large revision of all population data that the UN recently undertook [UN, 2000]. Nonetheless, the studies of income distribution referred to earlier have been based on the, obviously incorrect, unrevised population statistics. If these data are highly misleading, and differently so for individual countries, as indicated by the World Bank revision, this must have distorted the estimates of world income distribution to a large, although unquantified, extent.

\section{(c) Supplementary Indicators of Differences in Living Standards}

The studies hitherto referred to have measured inter-country and global distribution in terms of per capita income, which many consider to be an incomplete indicator of living standards. There are studies making international comparisons in other dimensions of welfare (e.g. [Crafts, 1999; Easterly, 1999; 2001; Easterlin, 2000]). It is not within the scope of this article to assess this considerable body of literature but it seems that when some alternative indicators, such as life expectancy at birth and literacy, are consulted, there is a convergence across countries over time (see also [Schultz, 1998; Melchior et at., 2000; Sala-i-Martin, 2002; Bourguignon and Morrison, 2002]).

\section{RELATIVE VERSUS ABSOLUTE INCOME DISTRIBUTION}


When estimating poverty, it has become standard to report both relative shares and absolute numbers, or head counts (see, for instance, [World Bank, 2000/01; Chen and Ravallion, 2001; Sala-i-Martin, 2002]). This is not the case when assessing income distribution in the world, however. All investigations covered in Table 1 have used different measures of relative income distribution (e.g. ratios and Gini). How the absolute income distribution across countries and globally has changed over time is largely ignored in the entire growth-cum-distribution literature. Dikhanov and Ward [2002] provide a table with estimated absolute income changes by income deciles over time, which we shall exploit below, but they do not elaborate the theme. ${ }^{\mathrm{xi}}$

\section{(a) Relative vs Absolute Global Income Distribution Since 1970}

In Figure 3, the absolute incomes of the world population by income deciles are shown for the two years 1970 and 1999 (as estimated by Dikhanov and Ward [2002: Table 2]). We see that most of the total growth in absolute incomes (in fact, 70 per cent) has taken place in the top decile (10th), where OECD populations account for about 85 per cent. The relative income growth has been highest in the 2 nd to 5 th deciles (numbers in italics on top of each bar), but the joint share of these deciles of absolute income growth is only 11 per cent (while most of the remaining 19 per cent accrued to the 9th decile). I have also inserted estimates from the same study of the most commonly used indicators of relative distribution, Gini and Theil, in Figure 3. These indicate a largely unaltered (relative) income distribution (and the estimates are quite similar to those derived in other studies for the same or close years; see Table 1).

[Figure 3 about here] 


\section{(b) Inevitable Widening Absolute Income Gaps}

While the relative world income distribution may not have changed much over recent decades and stands a chance of remaining relatively stable in the near future (see section $\mathrm{X}$ below), we can be completely certain that absolute income gaps will continue to grow

for at least one or two generations. To illustrate this, we return to the earlier example with the income distribution between India and the US. As reported in Table 2, there was an improvement in the (relative) income ratio between the two countries between 1960 and 1999, but when measured by Gini, the distribution remained unchanged. When the absolute income gap is employed as a third distribution indicator, the result is a deterioration in the distribution (from P\$13,185 to 28,450). The question is: How long will it take before India's per capita income starts to converge with that of America in absolute terms?

First an optimistic scenario: we postulate that India's per capita income growth will be a steady 6 per cent in the years to come (about 2 percentage points higher than during the 1990s), while it remains at 2 per cent in the US. In 20 years time, the per capita income in India will reach $\mathrm{P} \$ 7,180$, and increase in relative terms to 15.5 per cent of that in the US (Table 3, scenario 1). The absolute gap, however, will widen to about $\mathrm{P} \$ 39,180$. The outcome is a convergence of relative per capita incomes, but a divergence of absolute incomes.

In this scenario, the per capita income in India in the middle of the present century (P\$41,260) will, by far, have surpassed the 2000 income in the US (P\$31,200). Furthermore, the ratio of per capita incomes has increased to 49 per cent. Yet, the 
absolute gap in per capita income has grown to $\mathrm{P} \$ 42,740$. In this example, a decrease in the absolute gap will not appear until around 2050. It will hence take half a century-or close to two generations - before the absolute difference in per capita income begins to close, even if India's income were to grow three times faster than that of the US (Figure 4, upper panel). In a less optimistic scenario, where the postulated future annual per capita income growth in India is more moderate ( 3 per cent), but still higher than in the US ( 2 per cent), the absolute income gap will continue to grow far into the 22 nd century (Figure 4, lower panel).

\section{[Figure 4 about here]}

One can also look back in time and confirm that with a high annual per capita income growth, about 6 per cent, it has de facto been possible for a small number of countries to go from relative poverty to absolute incomes measuring up to those in Europe and the US over a span of 40 years. In 1960, Korea and Singapore had estimated per capita P\$ incomes of 9 and 23 per cent, respectively, of that in the US. At the time, Korea's per capita income was on the same level as that of many African countries. Some 40 years later, per capita income in Korea was at par with that of southern Europe, and about 10 times higher than in the majority of African countries. In the late 1990s, per capita incomes in Singapore and the US were about the same [World Bank, 2000/01]. What these simple 'compounded-interest examples' demonstrate is that for the absolute per capita income gap to start to close within the life time of the children born today, extraordinary growth rates are required in today's poorest countries — growth rates which only a few countries (Korea, Singapore and Taiwan) have thus far been able to maintain over long periods (see also endnote viii). 


\section{(c) What is Most Important?}

One can always discuss whether the gap between poor and rich countries-be it relative or absolute - is the most important, or if the level of per capita income in the now poorest countries is of greater importance. Many considerations suggest the latter. If a country like India can grow at a steady rate of 6 per cent per year, it will reach a per capita income of about $\mathrm{P} \$ 10,000$ within one generation (27 years), which is roughly half of the present average European income. This income level would be sufficient for the elimination of the worst consequences of current poverty in India: widespread under- and malnutrition, very high levels of child mortality and illiteracy extending over almost half of the population [Fogel, 1999; Svedberg, 2000]. It is also an income that would permit a general level of consumption four times higher than at present. With a per capita growth rate of 2 per cent, the average growth of India since its independence in 1950, this will take about 75 years.

\section{(d) Possible Consequences of a Continued Widening of Absolute Income Gaps}

It is somewhat misleading to present a higher per capita income growth rate in poor than in rich countries as 'income convergence' without reservation, as is routinely done in the growth-cum-distribution literature. A passage from Sala-i-Martin [2002: 36], one of the leading analysts in this field, is symptomatic: 'As China and India grew, the incomes of their numerous citizens tended to converge to those of the citizens of the rich world.' Sure enough, if an initially very poor country has a persistently higher per capita income growth than a rich country, its absolute per capita incomes will start to converge at some 
time in the future. As just demonstrated, this may take several generations with the growth rates accomplished by poor countries so far and meanwhile, the absolute percapita income gaps will inevitably widen.

Although the level of income in countries may be the most important aspect of development, the absolute gaps should not be ignored. One reason to pay more attention to absolute differences in incomes between countries is a normative 'global perspective of justness' [UNDP, 1999]. The one-sided emphasis on relative measures is one of the main reasons why economists have such difficulties in establishing a constructive dialogue with anti-globalisation activists and others primarily concerned with absolute differences [Kanbur, 2002]. In addition, there may be adverse consequences related to widening absolute income gaps that are overlooked. I will briefly mention, just as examples, three such possible consequences.

First, widening absolute income gaps may tempt the elite in the poorest countries to push for ever more unequal economic policies. In today's world, the highly educated in each and every country have access to the same information about the conditions in other countries. There is hence a risk that the elites in poor countries will increasingly identify themselves with the populations in the richest countries and 'demand' the same standard of living (absolute income). In low income countries, such demands can, in the short and medium term, only be met by a redistribution from the large majority of poor to the elite itself.

Second, widening the absolute income gaps across countries will create increased incentives for migration of both educated and unskilled labour from poor to rich countries. The migration of the educated is tantamount to a brain drain from poor 
countries and the dilution of already scant human capital, a crucial determinant of growth. Migration of unskilled labour from poor countries is something rich countries obviously want to regulate (to relatively low levels), and which de facto is often illegal (e.g. trafficking) and connected with other criminal activities.

Third, it is not inconceivable that growing absolute income gaps will lead to increased political tension between countries and an elevated risk of conflicts and wars. So far, research into this type of problems has primarily focused on relative income differences within countries (e.g. [Collier and Hoeffler, 1998]).

\section{PAST DEVELOPMENTS: SUMMARY AND CONCLUSIONS}

(a) Measurements and Methods

No single measure can provide a completely unambiguous answer to the question of whether income distribution across countries, or globally, has become more or less unequal in recent decades. Income and distribution are concepts that can be defined and measured in a number of ways and the basic income and population data at hand are flawed in various dimensions.

We have concluded, though, that FX\$ incomes are less comparable across countries than P\$ incomes. Studies solely based on FX\$ incomes [UNDP, 1999; Korceniewicz and Moran, 1997] must consequently be interpreted with scepticism. The P\$ incomes tend to underestimate differences across countries [Dowrick and Akmal, 2001], but are nowadays widely considered to be more to the mark.

When it comes to distribution indices, the choice must be based on the question posed. If the question is how the distribution of income between the very richest and 
poorest countries has evolved, an income ratio can be useful. When the entire distribution over all countries is the concern, comprehensive measures, such as the Gini coefficient, are warranted. Both sets of measures, however, have their limitations (p. 9 above).

Moreover, all estimates of changes in income distribution, irrespective of the income and distribution measures employed, are sensitive to which years are chosen for the investigation. The use of time series data for long periods is preferable to comparisons between two arbitrarily selected years. Furthermore, we have found it rather dubious to estimate (changes in) inter-national income distribution with measures not taking countries' population size into consideration. ${ }^{\text {xii }}$

Finally, there is the question of which basic income data are the most reliable and relevant, data from national accounts or household surveys. Both data sets are contaminated with measurement errors and there is yet no possibility to judge their relative reliability. The two data sets capture different incomes and without invoking normative judgement, it is not feasible to say which of these incomes are the most relevant proxies of well-being. Preferably, they should be used as two non-rival alternatives.

\section{(b) World Income Distribution: Which Way?}

Despite ambiguities in the choice of income and distribution measures, certain conclusions can be drawn on the basis of the assembled results in the available investigations. The conclusions presented below are primarily based on the studies that have employed (1) income measures adjusted for PPP, (2) weighted countries by population size, and (3) have used time series data. 
The first conclusion is that since the 1960s, the relative inter-national distribution of income, as measured by Gini and other comprehensive indicators, has remained rather stable. Most of the about 10 studies providing estimates for a long period, based on P\$ income data, have found a decline in the -0.02 to -0.05 interval. A few studies have estimated global distribution, i.e. also taking intra-country distribution into consideration, and found it to be more uneven than inter-national distribution. Most of these studies also suggest that global relative distribution has remained largely unaltered over the past few decades (a change in the $\pm 0.02-0.03$ range ). We can hence conclude that 'divergence, big time', which undoubtedly took place up to the mid 1960s, has come to a halt.

The relatively unchanged Gini coefficient conceals, however, that two contradictory forces have by and large neutralised each other. The relative spread in PPPadjusted per capita income has increased, but changes in countries' population shares have had offsetting effects, leaving Gini and other comprehensive measures relatively stable [Firebaugh, 1999: Table B1]. There are also important transitions lurking behind the largely constant Gini coefficient. Rapidly growing incomes in several middle-income countries (mainly in Southeast Asia) have contributed to a more unequal total distribution. xiii $^{\text {ii }}$

As noted by several authors, China's impact on world income distribution is of paramount importance because of the sheer size of its population (approaching 1.3 billion). It is hence important to recall that the reliability of the Chinese economic data leaves much to desire (see endnote ix). The decline in inter-national and global income inequality reported by Melchior et al. [2000], Sala-i-Martin [2002] and some other studies, is to a large extent the result of high growth in initially poor China, as reported in 
national account data (even when modified). Melanovic's [2002] finding that global income distribution has deteriorated (over a short period) is also mainly due to China. His results are chiefly driven by the use of income data from household surveys, which report much lower income growth rates, not only in rural China (with some 800 million people), but also in the other two initially poor populous rural countries in Asia, India and Bangladesh. Until we are able to more affirmatively gauge income growth and distribution in China, there will be remaining doubt on the direction in which world relative income distribution has changed in recent times (if at all).

A final conclusion regarding inter-country distribution is that there has been a marked increase in the relative difference in per-capita income between the absolutely poorest countries, almost all in Sub-Saharan Africa, and the richest countries (primarily within the OECD area), since the 1960s. This is shown most clearly by investigations based on income ratio measures, but also by those using comprehensive distribution measures, such as Gini (e.g. [Melchior et al., 2000; Sala-i-Martin, 2002]). As noted in several studies, the lack of growth in most African countries should be the main concern, not only for world income distribution, but considering the sharply increasing poverty. According to the estimate by Sala-i-Martin [2002: 39], in 1998, the African countries 'account for over 95 per cent of the world's poor.'

In sum, the most striking differences in the various estimates of changes in world income distribution have been reasonably well identified here, but the more subtle differences need more exploration. One such question is why investigations based on income data from national accounts [Sala-i-Martin, 2002] and household surveys [Milanovic, 2002], respectively, show global income distribution to evolve in different 
directions (over a short period). A tentative answer to this puzzle has been offered here (pp. 14-15), but further investigation is clearly required. There are also minor differences in estimated Gini coefficients, and changes therein, across studies that we have not explained. Considering that the various studies differ slightly in terms of the countries and years covered, and many other subtleties, these minor differences cannot be explained. This would require access to a complete and unflawed data set, encompassing all data applied in various individual studies.

\section{WHAT FUTURE DEVELOPMENTS ARE LIKELY?}

A main reason why relative inter-country income distribution, as measured by Gini and related measures, has remained largely unaltered in recent decades is notable changes in countries' shares of the world population [Firebaugh, 1999]. How the future relative distribution of incomes across countries will develop hence depends partly on the per capita economic growth that the respective groups of countries will manage to accomplish, and partly on relative population growth. If incomes in the now poorest countries are to grow faster than those in other countries, there will be an improvement in the relative income distribution. But if the poorest countries continue to account for rapidly expanding shares of the world population, this will tend to make the relative distribution more uneven. The question is hence what population and per capita income growth can be expected in coming decades.

\section{(a) Population Forecasts}


On average, the richest countries have had considerably lower population growth rates than the poor countries, but the trend is towards decreasing differences. According to the revised data from the World Bank [2000/01], the ratio of annual population growth in the low and middle income countries and the high income countries (per capita income in 1999 above $P \$ 9,200$ ) declined from 1.9/0.6 in the 1980s to 1.6/0.6 in the 1990s. A not too daring prognosis is that the difference in the population growth rate between poor and rich countries will continue to decrease in the future $[U N, 2000]$. Thus, there will be a smaller impact of changes in population shares on Gini and related distribution indicators. Consequently, differences in per capita income growth will be of increasing importance for how the (relative) distribution of income across countries will develop in years to come.

\section{(b) Expected Growth in Per Capita Real Income}

Economic growth theory does not provide much guidance, since the innumerable theoretical models developed in recent years predict divergent outcomes when it comes to growth in countries with different initial per capita income. The neo-classical Solow [1956] model, as well as some more recent (endogenous) growth models, predict convergence or neutrality (e.g. [Lucas, 1988]). Other models predict divergence, i.e. that the already rich countries will grow more rapidly than the poor (e.g. [Romer, 1990]) and that relative income distribution will thereby become more skewed with time.

Empirical research reveals a relatively strong correlation between a low initial income level and subsequent slow growth across countries (see [Temple, 1999] for a review). To explain this, some economists have found 'inherent' disadvantages for the 
poorest countries. Sachs and Werner [1997] primarily emphasise a tropical climate and high morbidity which reduce peoples' labour productivity and shorten their life spans. They have also identified other fixed growth deterrents, such as adverse natural preconditions for agriculture and geographical disadvantages in the form of long distances to the most important export markets. Other economists have interpreted the available empirical evidence differently and argued that the main reasons why growth has been lower in the poor countries are deficiencies in their basic institutions, such as nondemocratic regimes, widespread corruption and lax legal systems for ensuring property rights. Sala-i-Martin [1997] and many others also find support for the notion that many of these countries have pursued misguided economic policies.

In case the inherent disadvantages are the most important, the unavoidable conclusion is grim when it comes to expected future relative inter-country income distribution. On the other hand, if inadequate institutions and misdirected economic policies are the main hurdles for growth in the poorest countries, there is at least some hope for change — and thus for a more favourable development of future relative income distribution in the world.

\section{(c) Inevitable Widening Absolute Income Gaps}

It is indeed hazardous to predict future economic growth in different groups of countries and population projections are also uncertain. It is therefore almost impossible to forecast how inter-country income distribution in relative terms will develop in years to come-as measured by income ratios or Gini coefficients. What we can predict with complete certainty, however, is that the absolute per capita income gap between the richest and the 
poorest countries will inexorably continue to grow over the next two to three decades. There are no signs that economic growth in the rich countries is grinding to a halt, or even slowing down. This means that although the poorest countries may manage to increase their per capita growth rates to the level thus far proven to be the highest possible (about 6 per cent annually for a long period), the absolute income gap will continue to widen for several decades. If today's poor countries 'only' manage to grow a couple of percentage points quicker than the rich nations, there will be no decline in the absolute income gaps until some time in the 22nd century.

The nowadays comprehensive literature on income distribution in the world has almost exclusively focused on relative distribution. All the most conventional indicators (ratios and Gini) measure distribution in relative terms. To pay more heed to the growing absolute income gaps between rich and poor countries, and their consequences, seems an urgent task for future research into growth and distribution.

\footnotetext{
${ }^{\mathrm{i}} \mathrm{Li}$ et al. [1998] test the determinants of differences in the Gini coefficient on a panel of 166 observations from 49 countries. Their main finding is that credit constraints for the poor, which stifle their ability to invest in physical and human capital, constitute the chief explanation for high inequality. See also Aghion et al. [1999].

ii For other purposes, FX income measures may be more relevant, e.g. for 'assessing a nation's capacity to repay foreign debt or its bargaining power in international trade negotiations' [Dowrick and Akmal, 2001:2]

iii See Firebaugh [1999: 1606-09] for an elucidating demonstration of how these rather similar measures can be derived from one and the same general formula for income distribution.

iv It should be noted that I have used the same P\$ income data in both examples in order to highlight the difference induced by delineating rich and poor countries differently, holding other variables constant. The UNDP itself uses FX\$ income data in its estimations (see above).
} 
v Dikhanov and Ward [2002], employing income data corrected for substitution bias and the Theil index, find inter-country distribution to have deteriorated between the two years 1990 and 1999 (Theil increasing from 0.61 to 0.64 ).

${ }^{v i}$ Scanty income data is not the only problem when it comes to estimating changes in inter-national income distribution over long periods of time. Most of the countries of today (about 210) did not exist as nation-states a hundred years ago. Almost all of Africa was colonised and the majority of the countries in the Middle East were provinces in the Ottoman Empire. Prior to 1950, India included what are today Pakistan and Bangladesh (which then separated from Pakistan in 1971). A later, but similar, measurement problem is that after 1990, the Soviet Union split into some 25 countries without individual 'statistical histories'. This was one of the reasons why Schultz [1998] and Firebaugh [1999] used 1989 as the terminal year in their respective studies. Most other studies simply exclude the former Soviet republics.

vii In an attempt to update the World Bank's original 1P\$-a-day poverty line (P\$365 per year) to its 1999 equivalent, Dikhanov and Ward [2002] arrive at P\$700. With this inter-temporal 'PPP-exchange rate', $\mathrm{P} \$ 250$ in 1985 correspond to about $\mathrm{P} \$ 480$ in 1999.

viii According to table 23 in Milanovic's [2002] study, the combined inequality-increasing effect of low growth in rural China and India, and overall in Bangladesh, as compared to higher growth in the US and other large OECD countries, on global income deterioration accounted for 0.03 Gini points. That is, the entire net increase in global Gini reported by Milanovic can be explained by the estimated low growth in the rural areas in these populous Asian countries. It is further notable that in Milanovic's tables (19-23), reporting on the relative contribution of inter- and intra-country changes, respectively, to global distribution (i.e. changes in overall Gini), the growing inequality between urban and rural areas in the large Asian countries is counted as inter-country, not intra-country, effects.

ix There is widespread disbelief in the extraordinarily high growth rates reported in Chinese official documents. According to these estimates, China has had an annual GDP growth rate of about 10 per cent since 1980 [World Bank, 2000/01: Table 11]. Few seem to believe this number to be reliable and alternative estimates have been provided. The official growth number has been scaled down by Sala-iMartin [2002], as well as by Dikhanov and Ward [2002], to the more modest, although still high, growth rate estimated by Maddison [1998].

$x$ Another way of judging whether a change in Gini by 0.03 points is large or small is to look at the variation in Gini across developing countries, which ranges from about 0.30 to well above 0.60 [World Bank, 2000/01].

xi Also Pritchett [1997] and Radetzki and Jonson [2001] present data on absolute income disparities across countries, but do not explore the developments and consequences.

xii In other endeavours, such as estimating determinants of income growth differences across countries in growth regressions, where each country is one unit of observation, unweighted income data are preferable. xiii A further observation, not discussed in this study, is the strong convergence of incomes that has taken place within the OECD block [Gottschalk and Smeeding, 1997]. 
Global-income-dist-01-references.doc /JDS-03/2003-01-27/03-08-04

\section{References:}

Aghion, P., E. Caroli, and C. Garcia-Penalosa 1999, 'Inequality and Economic Growth: The Perspectives of the New Growth Theories', Journal of Economic Literature, Vol.37, No.4, pp.1615-60.

Alesina A. and D. Rodrik 1994, 'Distributive Politics and Economic Growth', Quarterly Journal of Economics, Vol.109, No.2, pp.465-90.

Atkinson, A.B. and A. Brandolini 2001, "Promises and Pitfalls in the use of "Secondary" Data Sets: Income Inequality in OECD Countries as a Case Study', Journal of Economic Literature, Vol.XXXIX, No.3, pp.771-800.

Barro, R. 2000, 'Inequality and Growth in a Panel of Countries', Journal of Economic Growth, Vol.5, No.1, pp.5-32.

Bils, M. and P.J. Klenow 2001, 'Quantifying Quality Growth', American Economic Review, Vol.91, No.4, pp.1006-30.

Boltho, A. and G. Toniolo 1999, 'The Assessment: The Twentieth CenturyAchievements, Failures, Lessons', Oxford Review of Economic Policy, Vol.15, No.4, pp.18-34.

Boskin, M.J., E.R. Dulberger, R.J. Gordon, Z. Griliches and D.W. Jorgenson 1997, 'The CPI Commission: Findings and Recommendations', American Economic Review, Vol.87, No.2, pp.78-83.

Bourguignon, F. and C. Morrisson 2002, 'Inequality Among World Citizens: 1820-1992', American Economic Review, Vol.92, No.4, pp.727-44. 
Chen, S. and M. Ravallion 2001, 'How did the World Poorest Fare in the 1990s?', Review of Income and Wealth, Vol.47, No.3, pp.283-300.

Clarke, G.R.G. 1995 'More Evidence on Income Distribution and Growth', Journal of Development Economics, Vol.47, No.2, pp.403-27.

Collier, P. and A. Hoeffler 1998, 'On Economic Causes of Civil War', Oxford Economic Papers, Vol.50, No.4, pp.563-73.

Costa, D.L. 2001, 'Estimating Real Income in the United States from 1888 to 1994 : Correcting CPI Bias Using Engel Curves', Journal of Political Economy, Vol.109, No.6, pp.1288-1310.

Crafts, N. F. R. 1999, 'Economic Growth in the Twentieth Century', Oxford Review of Economic Policy, Vol.15, No.4, pp.1-17.

Deaton, A. 2001, 'Counting the World's Poor: Problems and Possible Solutions', World Bank Research Observer, Vol.16, No.2, pp.125-47.

Deaton, A. 2003, 'Health, Inequality, and Economic Development', Journal of Economic Literature, Vol.XLI, No.2, pp.113-158.

Deininger, K. and L. Squire 1996, 'A New Data Set Measuring Income Inequality', World Bank Economic Review, Vol.10, No.3, pp.565-91.

Deininger, K. and L. Squire 1998, 'New Ways of Looking at Old Issues: Inequality and Growth', Journal of Development Economics, Vol.57, No.2, pp.259-87.

Dikhanov, Y. and M. Ward 2002, 'Evolution of the Global Distribution of Income in 1970-99' (version 0.2; available at www.warwick.ac.uk/fac/soc/CSGR/ Pdikhanov). 
Dollar, D. and A. Kraay 2002, 'Growth Is Good for the Poor', Journal of Economic Growth, Vol.7, No.3, pp.195-225.

Dowrick, S. and M. Akmal 2001, 'Contradictory Trends in Global Income Inequality: A Tale of Two Biases' (available at: http://ecocomm.anu.edu au/economics)

Dowrick, S. and J. Quiggin 1997, 'True Measures of GDP and Convergence', American Economic Review, Vol.87, No.1, pp.41-64.

Easterlin, R. A. 2000, 'The World Standard of Living Since 1800', Journal of Economic Perspectives, Vol.14, No.1, pp.2-26.

Easterly, W. 1999, 'Life During Growth, Journal of Economic Growth, Vol.4, No.3, pp.239-76.

Easterly, W. 2001, The Elusive Quest for Growth, Cambridge: MIT Press.

Firebaugh, G. 1999, 'Empirics of World Income Inequality', American Journal of Sociology, Vol.104, No.6, pp.1597-1630.

Fogel, R. W. 1999, 'Catching Up with the Economy', American Economic Review, Vol.89, No.1, pp.1-21.

Forbes, K.J. 2000 'A Reassessment of the Relationship Between Inequality and Growth', American Economic Review, Vol.90, No.4, pp.869-87.

Gottschalk, P. and T.M. Smeeding 1997, 'Cross-National Comparisons of Earnings and Income Inequality', Journal of Economic Literature, Vol.35, No.2, pp.633-87.

Hamilton, B.W. 2001, ‘Using Engel’s Law to Estimate CPI Bias’, American Economic Review, Vol.91, No.3, pp.619-30.

Hausman, J. 2003, 'Sources of Bias and Solutions to Bias in the Consumer Price Index', Journal of Economic Perspectives, Vol.17, No.1, pp.23-44. 
Heston, A. 1994, 'A Brief Review of some Problems in Using National Accounts Data in Level of Output Comparisons and Growth Studies', Journal of Development Economics, Vol.44, No.1, pp.29-52.

International Comparison Program (ICP) 2002, 'Origins of the United Nations International Comparison Program' (available at: http://pwt.econ.edu/icp).

Jones, C. I. 1997, On the Evolution of World Income Distribution', Journal of Economic Perspectives, Vol.11, No.3, pp.19-36.

Kanbur, R. 2002, 'Economics, Social Science and Development', World Development, Vol.30, No.3, pp.477-86.

Korzeniewicz, R. P. and T.P. Moran 1997, 'World-economic Trends in the Distribution of Income, 1965-1992', American Journal of Sociology, Vol.102, No.4, pp.100039.

Li, H., L. Squire and H. Zou 1998, 'Explaining International and Intertemporal Variations in Income Inequality', Economic Journal, Vol.108, No.1, pp.26-43.

Lucas, R. E. 1988, 'On the Mechanisms of Economic Development', Journal of Monetary Economics, Vol. 22, No.1, pp.3-42.

Maddison, A. 1995, Monitoring the World Economy 1820-1992, Paris: OECD Development Centre.

Maddison, A. 1998, Chinese Economic Performance in the Long Run, Paris: OECD. Melchior, A., K. Telle, and H. Wiig 2000, Globalisation and Inequality: World Income Distribution and Living Standards, 1960-1998, Royal Norwegian Ministry of Foreign Affairs, Report 6B: 2000. 
Milanovic, B. 2002, 'True World Income Distribution, 1988 and 1993: First Calculation Based on Household Surveys Alone', Economic Journal, Vol.112, No.1, pp.5192.

Perotti. R. 1996, 'Growth, Income Distribution and Democracy', Journal of Economic Growth, Vol.1, No.2, pp.149-187.

Persson, T. and G. Tabellini 1994, 'Is Inequality Harmful for Growth?', American Economic Review, Vol.84, No.3, pp.600-21.

Pritchett, L. 1997, 'Divergence: Big Time', Journal of Economic Perspectives, Vol.11, No.3, pp.3-17.

Pyatt, G. 1976, 'On the Interpretation and Disaggregation of Gini Coefficients', Economic Journal, Vol.86, No.2, pp.243-55.

Quah, D. T. 1996, 'Empirics for Economic Growth and Convergence', European Economic Review, Vol.40, No.6, pp.1353-75.

Radetzki, M. and B. Jonsson 2001, 'The Expanding Global Income Gap: How Reliable is the Evidence?', European Journal of Development Research, Vol.14, No.1, pp.243-63.

Rao, D.S.P. 2002, 'Construction of Purchasing Power Parities (PPPs) for the Study of Global and Regional Poverty', paper for Seminar on the ICP, March 2002 (available at: www.worldbank.org/data/icp).

Ravallion, M. 2001, 'Growth, Inequality and Poverty: Looking Beyond Averages', World Development, Vol.29, No.11, pp.1803-15.

Reddy, S.G. and T.W. Pogge 2002, 'How Not to Count the Poor' (version 4.4; available at: www.socialanalysis.org). 
Romer, P. 1990, 'Endogenous Technological Change', Journal of Political Economy, Vol.98, No.5, pp.S71-S102.

Sachs, J. and A. M. Werner 1997, 'Fundamental Sources of Long-term Growth', American Economic Review, Vol.87, No.2, pp.184-88.

Sala-i-Martin, X. 1997, 'I Just Ran Two Million Regressions', American Economic Review, Vol.87, No.2, pp.178-83.

Sala-i-Martin, X. 2002, 'The Disturbing "Rise” of Global Income Inequality', NBER Working Paper, 8904.

Schneider, F. and D. Enste 2000, 'Shadow Economies: Size, Causes, and Consequences', Journal of Economic Literature, Vol.38, No.1, pp.77-114.

Schultz, T. 1998, 'Inequality in the Distribution of Personal Income in the World: How it is Changing and Why', Journal of Population Economics, Vol.11, pp.307-44.

Solow, R. M. 1956, 'A Contribution to the Theory of Economic Growth', Quarterly Journal of Economics, Vol.70, No.1, pp.65-94.

Svedberg, P. 2000, Undernutrition and Poverty: Theory, Measurement and Policy, Oxford: Oxford University Press.

Temple, J. 1999, 'The New Growth Evidence', Journal of Economic Literature, Vol.37, No.1, pp.112-56.

UN 2000, World Population Prospects, the 2000 Revision, New York.

UNDP 1999, Human Development Report 1999, Vienna: UNDP.

World Bank 1999/00, World Development Report 1999/00, New York: Oxford University Press. 
World Bank 2000/01, World Development Report 2000/01, New York: Oxford University Press.

World Bank 2002a, World Development Report 2002, New York: Oxford University Press.

World Bank 2002b, Papers for International Conference on ICP (available at: www.worldbank.org/data/icp/papers.htm). 
JDS-incomedist-tab.doc; 2001-11-30; Peter Svedberg /C >JDS-03/Revised version:03-07-12/

TABLE 1

RESULTS, METHODS AND MEASUREMENTS IN THE VARIOUS STUDIES OF CHANGES IN THE DISTRIBUTION OF PER CAPITA INCOME ACROSS COUNTRIES AND GLOBALLY

\begin{tabular}{|l|l|l|l|l|}
\hline Author(s) & Main results (change in income distribution over time) & Years & Distri- & Income \\
Year $^{\mathrm{a}}$ & & cove- & bution & mea- \\
& & red $^{\mathrm{b}}$ & measure $^{\mathrm{c}}$ & sure $^{\mathrm{d}}$ \\
\hline
\end{tabular}

\begin{tabular}{|c|c|c|c|c|}
\hline $\begin{array}{l}\text { 1. UNDP } \\
1999\end{array}$ & $\begin{array}{l}\text { Drastic increase of the per capita income ratio between rich } \\
\text { and poor countries (IR from } 30 \text { to } 74 \text { ) }\end{array}$ & $\begin{array}{l}1960 / \\
1997\end{array}$ & IR & FX\$ \\
\hline $\begin{array}{l}\text { 2. World } \\
\text { Bank 2000/1 }\end{array}$ & $\begin{array}{l}\text { Large increase of the per capita income ratio between rich } \\
\text { and poor countries (IR from } 18 \text { to } 37 \text { ) }\end{array}$ & $1960 /$ & IR & P\$ \\
\hline $\begin{array}{l}\text { 3. Radetzki } \\
2001\end{array}$ & $\begin{array}{l}\text { Improved inter-country distribution when measured by Gini } \\
\text { and } \mathrm{P} \$ \text { income data (from } 0.54 \text { to } 0.49 \text { ). }\end{array}$ & $\begin{array}{l}1960 / \\
1995\end{array}$ & $\begin{array}{l}\text { Gini } \\
\text { IR }\end{array}$ & $\begin{array}{l}\text { FX\$ } \\
(\mathrm{P} \$)\end{array}$ \\
\hline $\begin{array}{l}\text { 4. Korcenie- } \\
\text { wicz } 1997\end{array}$ & $\begin{array}{l}\text { Global and inter-country distribution more uneven when } \\
\text { FX\$ income data (only) are used }\end{array}$ & $\begin{array}{l}1965 / / \\
1992\end{array}$ & $\begin{array}{l}\text { Gini } \\
\text { Theil }\end{array}$ & FX\$ \\
\hline $\begin{array}{l}\text { 5. Pritchett } \\
1997\end{array}$ & $\begin{array}{l}\text { Increase of the ratio between per capita incomes in the } 17 \\
\text { richest country to all other countries (from } 4.2 \text { to } 4.5 \text { ) }\end{array}$ & $\begin{array}{l}1960 / \\
1990\end{array}$ & IR & PPP\$ \\
\hline $\begin{array}{l}\text { 6. Jones } \\
1997\end{array}$ & $\begin{array}{l}\text { Modest decrease in the number of countries with less than } \\
10 \text { per cent of US per worker income (P\$) }\end{array}$ & $\begin{array}{l}1960 / \\
1988\end{array}$ & IR & $\begin{array}{l}\mathrm{P} \$ \\
(\mathrm{FX} \$)\end{array}$ \\
\hline $\begin{array}{l}\text { 7. Firebaugh } \\
1999\end{array}$ & $\begin{array}{l}\text { Income distribution of incomes across countries remained } \\
\text { unaltered by several distribution measures }(\mathrm{P} \$)\end{array}$ & $\begin{array}{l}1965 / / \\
1989\end{array}$ & $\begin{array}{l}\text { Gini } \\
\text { Theil+ }\end{array}$ & $\begin{array}{l}\mathrm{P} \$ \\
(\mathrm{FX} \$)\end{array}$ \\
\hline $\begin{array}{l}\text { 8. Boltho } \\
1999\end{array}$ & $\begin{array}{l}\text { Drastic increase in global inequality up to } 1980 \text {; modest } \\
\text { decline thereafter }\end{array}$ & $\begin{array}{l}1900 / / \\
1998\end{array}$ & Gini & P\$ \\
\hline $\begin{array}{l}\text { 9. Melchior } \\
2000\end{array}$ & $\begin{array}{l}\text { Income distribution across countries more even (Gini from } \\
0.59 \text { to } 0.52 \text { ). Income ratio declined (P\$) }\end{array}$ & $1965-$ & $\begin{array}{l}\text { Gini+ } \\
\text { IR }\end{array}$ & $\begin{array}{l}\mathrm{P} \$ \\
(\mathrm{FX} \$)\end{array}$ \\
\hline
\end{tabular}




\begin{tabular}{|c|c|c|c|c|}
\hline $\begin{array}{l}\text { 10. Schultz } \\
1998\end{array}$ & $\begin{array}{l}\text { Inter-country income distribution largely unchanged with } \\
\text { all distribution indicators (P\$) }\end{array}$ & $1960-$ & Gini & $\begin{array}{l}\mathrm{P} \$ \\
(\mathrm{FX} \$)\end{array}$ \\
\hline $\begin{array}{l}\text { 11. Dowrick } \\
2001\end{array}$ & $\begin{array}{l}\text { Small increase or decline in inter-country distribution } \\
\text { depending on the measure used }\end{array}$ & $\begin{array}{l}1980 / \\
1993\end{array}$ & $\begin{array}{l}\text { Gini } \\
\text { Thiel+ }\end{array}$ & $\begin{array}{l}\text { P\$-A } \\
\text { FX\$ }\end{array}$ \\
\hline $\begin{array}{l}\text { 12. Sala-i- } \\
\text { Martin } 2002\end{array}$ & $\begin{array}{l}\text { Decline in inter-country and global inequality with all } \\
\text { distribution indicators (global Gini from } 0.63 \text { to } 0.62 \text { ) }\end{array}$ & $\begin{array}{l}1970- \\
1998\end{array}$ & $\begin{array}{l}\text { Gini } \\
\text { Theil+ }\end{array}$ & $\begin{array}{l}\mathrm{P} \$ \\
(\mathrm{FX} \$)\end{array}$ \\
\hline $\begin{array}{l}\text { 13. Milanovic } \\
2002\end{array}$ & $\begin{array}{l}\text { Global distribution of incomes across households in the } \\
\text { world more uneven (Gini from } 0.63 \text { to } 0.66 \text { ) }\end{array}$ & $\begin{array}{l}1988 / \\
1993\end{array}$ & $\begin{array}{l}\text { Gini } \\
\text { Theil+ }\end{array}$ & P\$ \\
\hline $\begin{array}{l}\text { 14. Dikhanov } \\
2002\end{array}$ & $\begin{array}{l}\text { Global and inter-country distribution more uneven (Global } \\
\text { Gini from } 0.67 \text { to } 0.68 \text {; Theil from } 0.82 \text { to } 0.91 \text { ) }\end{array}$ & $\begin{array}{l}1970 / / \\
1999\end{array}$ & $\begin{array}{l}\text { Gini } \\
\text { Theil+ }\end{array}$ & P\$-A \\
\hline $\begin{array}{l}\text { 15. Bourguig- } \\
\text { non } 2002\end{array}$ & $\begin{array}{l}\text { Drastic increase in global income inequality 1820-1960; } \\
\text { relatively stable thereafter }\end{array}$ & $\begin{array}{l}1820 / / \\
1992\end{array}$ & $\begin{array}{l}\text { Gini } \\
\text { Theil+ }\end{array}$ & P\$ \\
\hline
\end{tabular}

a) Only the first author of the article is mentioned; see reference list for more details.

b) Years expressed as 1960-1995 mean that distribution estimates have been derived for each year within the period. Years expressed as 1960/1995 mean income distribution estimates for these two years and years expressed as 1970//1998 mean that three or more individual years within this time span have been covered.

c) IR stands for Income Ratio (which can be defined and measured in different ways; see the main text). To economise on space, only the main distribution indexes are mentioned in this column. In many of the articles, several additional comprehensive distribution indices are also applied (e.g. LogVar and $\mathrm{CV}^{2}$ ); when so, this is indicated by + .

d) All studies (except 6 and 13; see these entries) use Gross Domestic Product (GDP) per capita in constant dollars as the proxy for per capita income. FX\$ means that income in US dollars has been converted by current exchange rates (FX). P\$ means that income data have been adjusted for purchasing power parity (PPP) differences. P\$-A means that the P\$ estimate has been corrected for substitution bias (see main text) with the Afriat index number approach. 
TABLE 2

TOTAL GDP AND POULATION IN INDIA AND THE US IN 1960 AND 1999 ASOLUTE AND RELATIVE INCOME DISTRIBUTION (MAIN INDICATORS IN BOLD)

\begin{tabular}{|c|c|c|c|c|c|c|c|c|c|}
\hline & \multicolumn{2}{|c|}{$\begin{array}{l}\text { Total GDP } \\
\text { (1999 P\$ billion) }\end{array}$} & \multicolumn{2}{|c|}{$\begin{array}{l}\text { Total population } \\
\text { (million) }\end{array}$} & \multicolumn{2}{|c|}{$\begin{array}{l}\text { GDP per cap. } \\
\text { (1999 P\$) }\end{array}$} & \multicolumn{3}{|c|}{$\begin{array}{l}\text { Annual growth 1960- } \\
99 \text { (per cent per year) }\end{array}$} \\
\hline & 1960 & 1999 & 1960 & 1999 & 1960 & 1999 & GDP & Pop & GDP/c \\
\hline \multicolumn{10}{|c|}{ Absolute numbers } \\
\hline India & 369 & 2,144 & 452 & 998 & 815 & 2,150 & 4.5 & 2.0 & 2.5 \\
\hline US & 2,560 & 8,350 & 183 & 273 & 14,000 & 30,600 & 3.0 & 1.0 & 2.0 \\
\hline Total & 2,929 & 10,494 & 635 & 1,271 & .. & .. & .. & .. & .. \\
\hline Gap (India-US) &.. &.. &.. &.. & $-13,185$ & $-28,450$ &.. &.. &.. \\
\hline \multicolumn{10}{|c|}{ Per cent distribution } \\
\hline India & 13 & 20 & 71 & 78 & .. & .. & .. & .. & .. \\
\hline US & 87 & 80 & 29 & 22 & .. & .. & .. & .. &.. \\
\hline Total & 100 & 100 & 100 & 100 & .. & .. & .. & .. & .. \\
\hline Ratio (India/US) & .. & .. & .. & .. & 5.8 & 7.0 &.. &.. & .. \\
\hline Gini coefficient & .. & .. & .. & .. & 0.58 & 0.58 & .. & .. & .. \\
\hline
\end{tabular}

Sources: Total GDP and size of population in 1999 are from the World Bank [2000/01: tables 1 and 11].

The rates of growth of GDP and population are derived from various issues of the World Development Report and are rounded, approximative numbers. The estimates of total GDP P\$ and population in 1960 are derived from these growth rates and the absolute numbers for 1999. 
TABLE 3

SIMULATED ABSOLUTE INCOME GAP BETWEEN PER CAPITA INCOME

IN INDIA AND THE US, TWO SCENARIOS

\begin{tabular}{|c|c|c|c|c|c|c|c|}
\hline & & \multicolumn{3}{|c|}{ Scenario 1} & \multicolumn{3}{|c|}{ Scenario 2} \\
\hline & $\begin{array}{l}\text { GDP/c } \\
2000\end{array}$ & $\begin{array}{l}\text { Growth } \\
\text { GDP/c }\end{array}$ & $\begin{array}{l}\text { GDP/c } \\
2020\end{array}$ & $\begin{array}{l}\text { GDP/c } \\
2050\end{array}$ & $\begin{array}{l}\text { Growth } \\
\text { GDP/c }\end{array}$ & $\begin{array}{l}\text { GDP/c } \\
2020\end{array}$ & $\begin{array}{l}\text { GDP/c } \\
2050\end{array}$ \\
\hline India & 2,240 & $6 \%$ & 7,180 & 41,260 & $3 \%$ & 4,050 & 9,820 \\
\hline US & 31,200 & $2 \%$ & 46,360 & 84,000 & $2 \%$ & 46,360 & 84,000 \\
\hline Absolute gap (India-US) & $-13,185$ & .. & $-39,180$ & $-42,740$ & .. & $-42,310$ & $-74,180$ \\
\hline Income ratio (India/US) & 7.2 & .. & 15.5 & 49.1 & .. & 8.7 & 11.7 \\
\hline
\end{tabular}

Source: World Bank [2002] (GDP per capita in year 2000) and author's calculations 
FIGURE 1

LORENTZ DIAGRAM SHOWING THE RELATIVE DISTRIBUTION OF INCOME IN A HYPOTHETICAL POPULATION

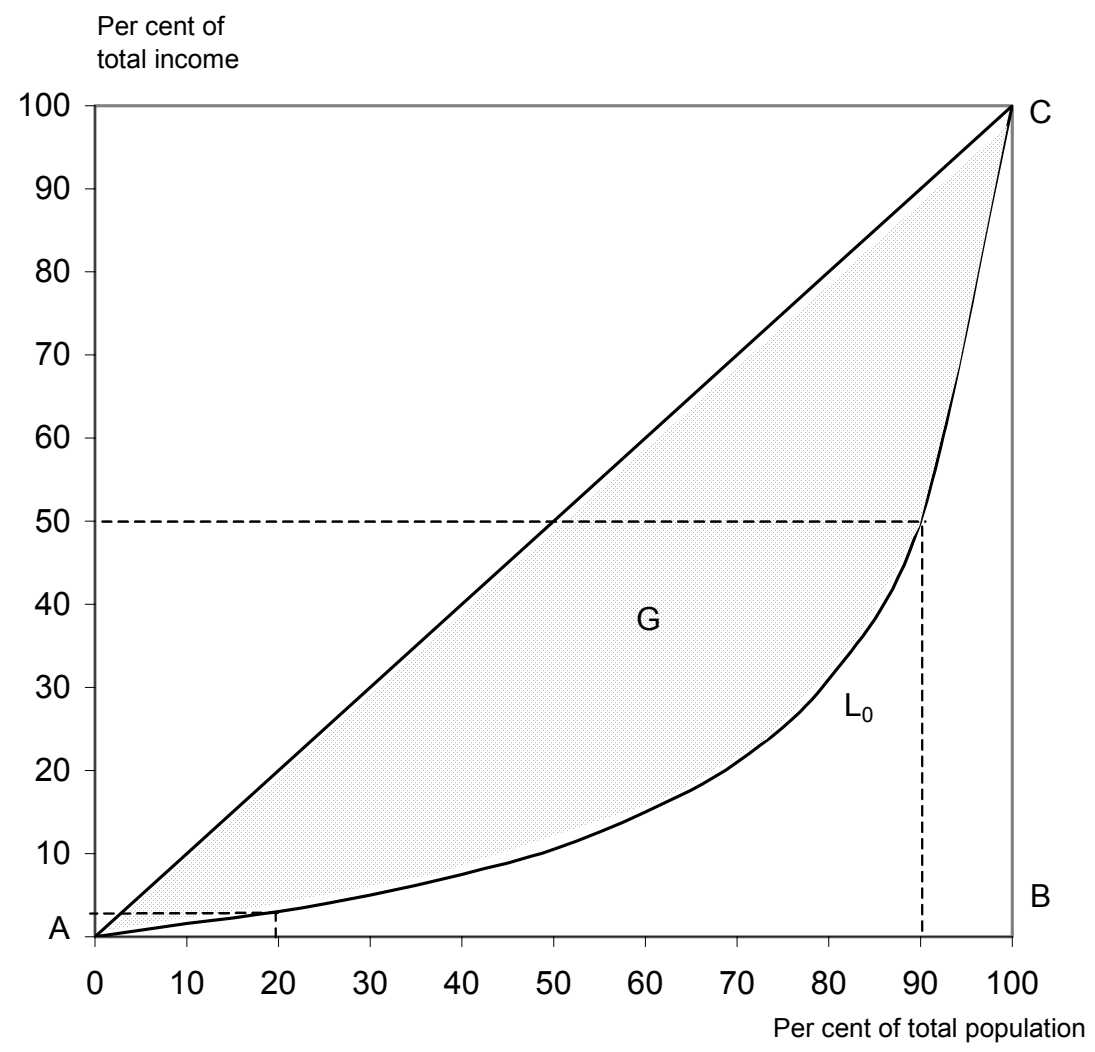


FIGURE 2

LORENZ DIAGRAM SHOWING THE RELATIVE DISTRIBUTION

OF INCOME BETWEEN THE USA AND INDIA, 1960 AND 1999

Per cent of

total income

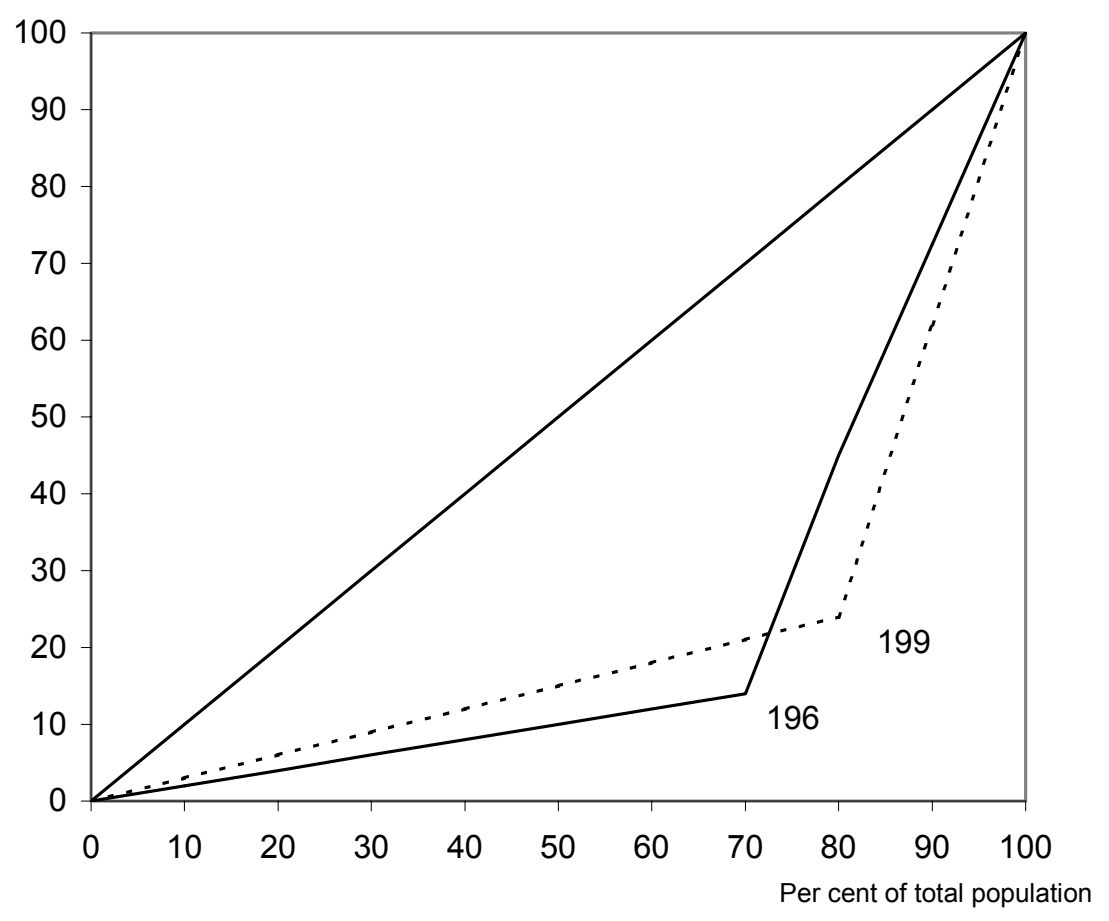


FIGURE 3

ABSOLUTE AND RELATIVE INCOME DISTRIBUTION ACROSS HOUSEHOLDS IN THE WORLD, 1970 AND 1999

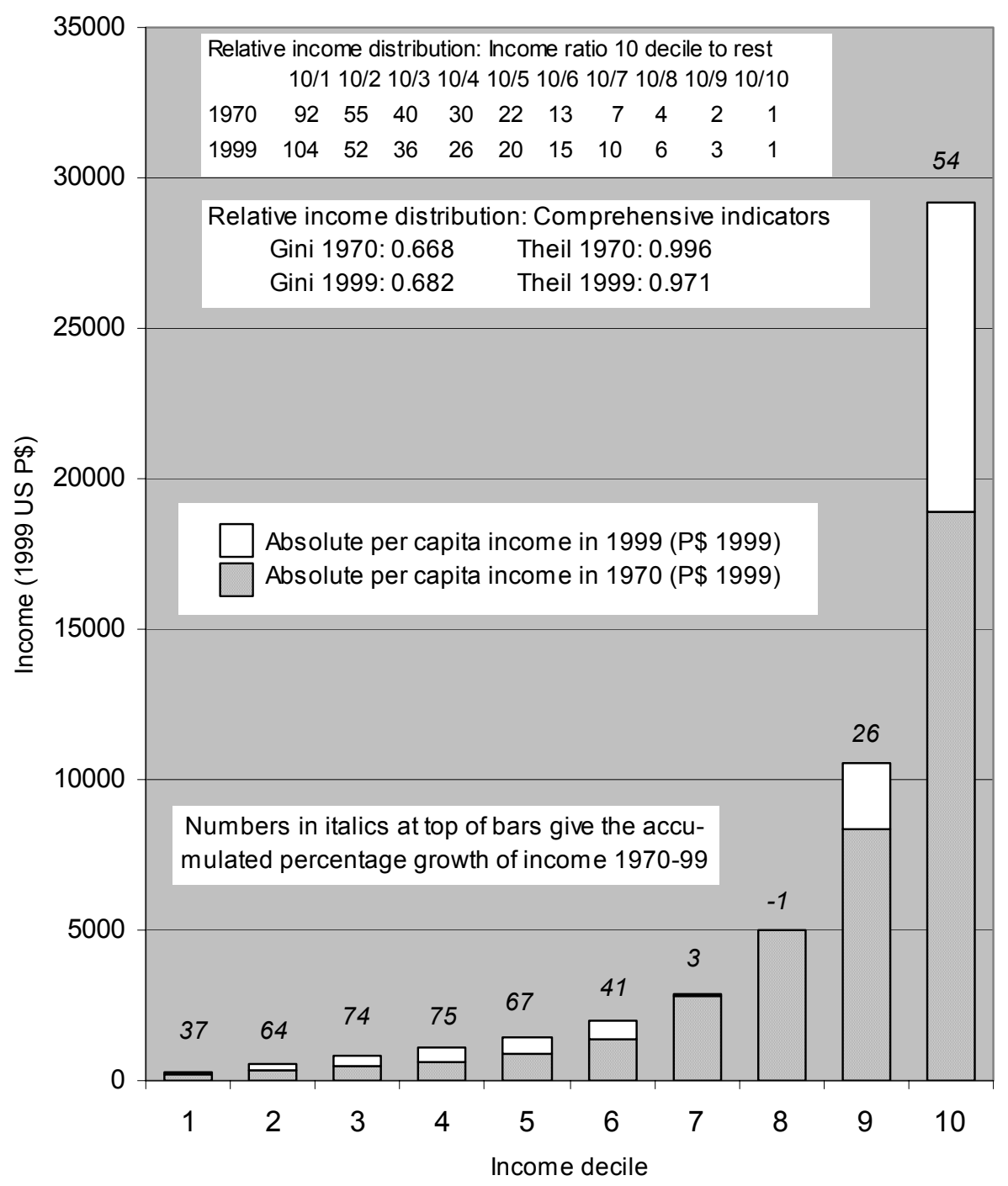

Source: basic data from Dikhanov and Ward [2002] 
FIGURE 4

SIMULATION OF FUTURE GAP IN GDP PER CAPITA BETWEEN INDIA AND USA: TWO SCENARIOS

\section{Scenario 1}

GDP per capita
(1000 US P\$)

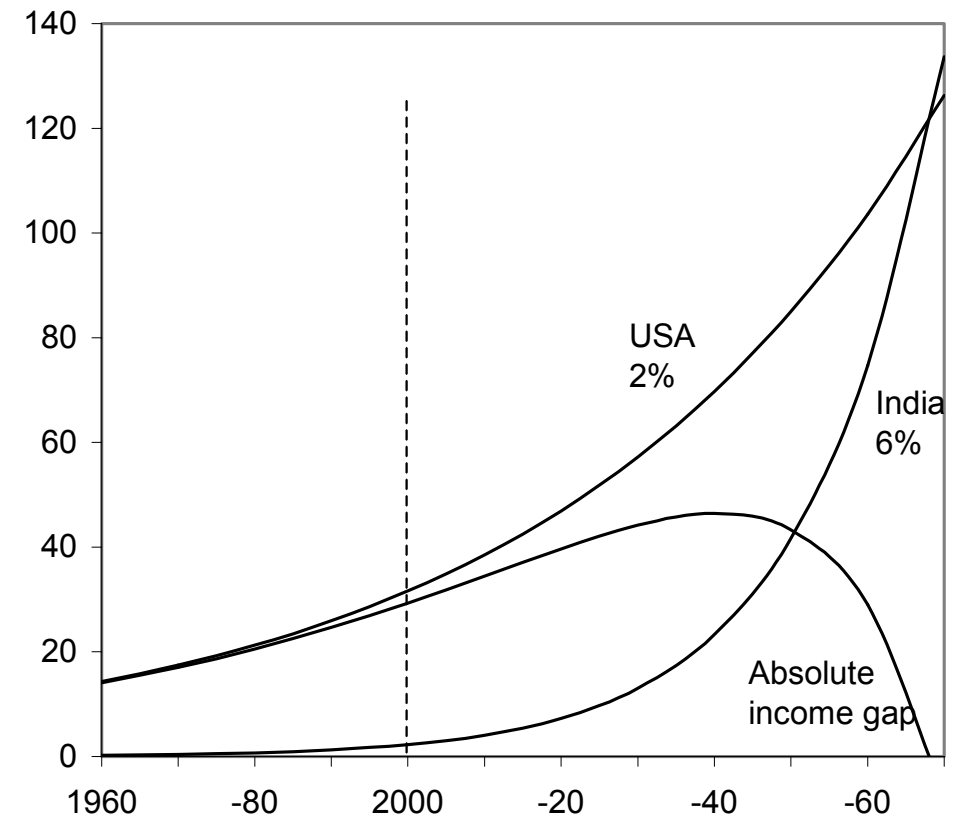

\section{Scenario 2}

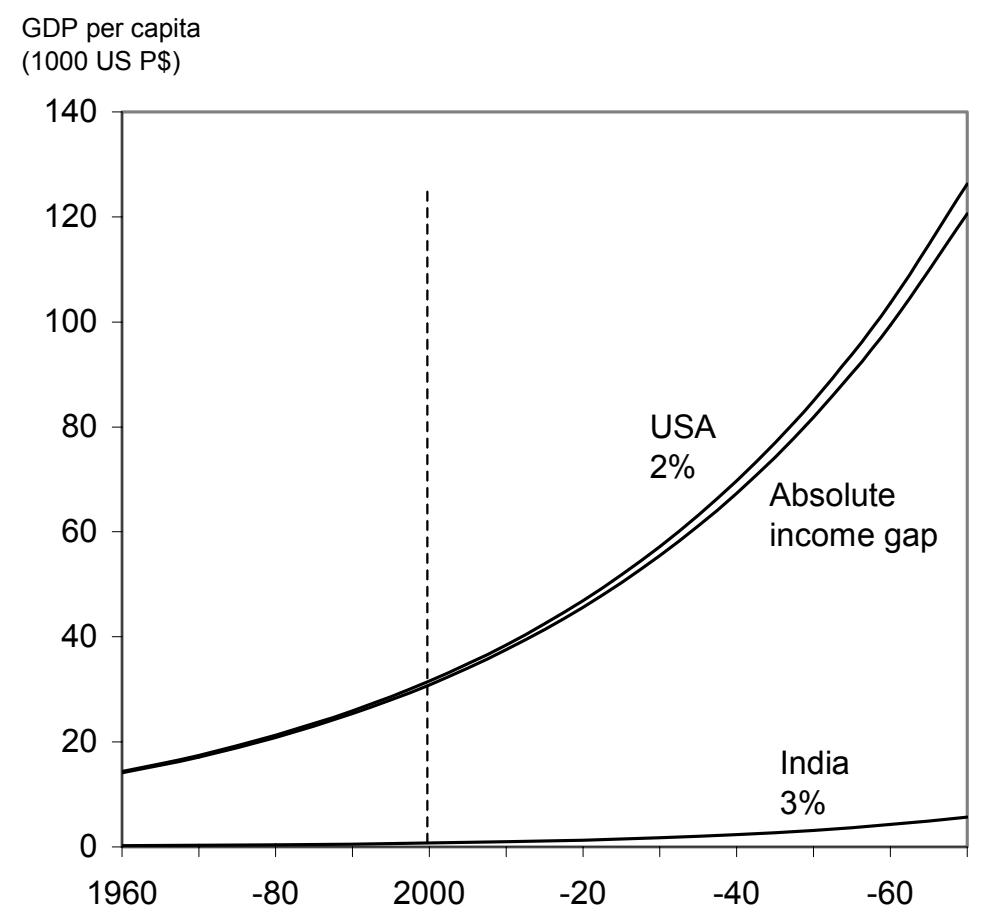




\section{SEMINAR PAPER SERIES}

The Series was initiated in 1971. For a complete list of Seminar Papers, please contact the Institute.

$\underline{2003}$

717. Assar Lindbeck

Improving the Performance of the European Social Model The Welfare State over the Life Cycle.

718. Harry Flam

Turkey and the EU: Politics and Economics of Accession.

719. Assar Lindbeck

An Essay on Welfare State Dynamics.

720. Gino A. Gancia

Globalization, Divergence and Stagnation.

721. Dirk Niepelt

Tax Evasion Dynamics.

722. Dirk Niepelt

Intra-Generational Conflict: The Role of Balanced Budget Rules.

723. Peter Svedberg and John E. Tilton

The Real Real Price of Nonrenewable Resources: Copper 18702000 .

724. Peter Svedberg

World Income Distribution: Which Way?

ISSN 0347-8769

Stockholm, 2003

Institute for International Economic Studies 